\title{
Penitentiary Dreams: Books Will Take You Anywhere You Want to Go Stephen C. Richards
}

\section{INTRODUCTION}

Higher education is a journey with no end; books open on the world and take us many places, some of them less pleasant than others. I have always loved to read, and for this, like most of the wonders of this life, there is a price to pay.

I entered federal prison not as a convicted criminal, but a prisoner of the drug war. I would do hard time in maximum security for failure to cooperate with federal authorities in the persecution and destruction of others. As a result, I would lose a wife, son, and home. Still, I had my health and strong mind; now I would need to bury the past, and invent new dreams. I reached back to a happier time-when I was a university student studying sociology. I started college in 1969, and left in 1972 without a degree. I entered prison determined to somehow complete that degree. Upon leaving prison I went to graduate school. Today, I am an associate professor of sociology and criminology. This is the story of how I managed to pursue a "higher education" in federal prison.

In this essay I recall, as best I remember, how I got into this mess, penitentiary dreams, the books I read in prison, classes in prison, taking college correspondence courses, completing a college degree, graduate school, becoming a professor, and conclude with a guide to university credits for prisoners.

\section{HOW I GOT INTO THIS MESS}

Upon graduation from high school in 1969, I began my higher education at the University of Wisconsin-Madison (UW). The university community, like Berkeley, Columbia, and dozens of other campuses in the US, was busy with the social revolution of the late 1960 s, including protest marches for civil rights and against the war in Indochina.

As a student with a romantic political conscience, and deeply impressed with the hippie movement that dared to question nearly everything, I joined the fray, and was radicalized by police assaults with gas and riot batons. Reading in sociology, history, and political science reinforced my aversion to the daily 
body counts in Vietnam, and like many students, encouraged idealistic views that we had a moral duty to help bring the war to an end.

At UW I remember taking courses about China, Latin America, and Africa, and I learned that my government opposed liberation movements all over the world. I was struck by the fact that there are, at the very least, three separate worlds existing side by side. I was born of the first world, which is composed of the rich industrial countries. The second world is the so-called developing countries, where the first world has elected to deploy some investment capital. The third world is the domain of countries that are largely seen by American and European bankers as places to extract mineral resources, rather than to allow economies to develop as a means to raise the standard of living for the indigenous population.

In 1970, my head filled with the ideas of Frantz Fanon (1976a, 1976b), Regis Debray (1980), and B. Traven (1970, 1972, 1991), I left the land of privilege and traveled to Mexico for the first time. I should have stuck to the tourist destinations, but no, I had to seek adventure, get to know the people, and venture beyond the pale. Mexico is a country that may be characterized as balancing on the edge of the second and third world; a large nation, with vast potential, but with serious economic disparities. The Mexican elite is very rich, and most everybody else dirt poor. I quickly found myself mesmerized by a country dominated by a ruthless upper class, mired in poverty, and with a long history of failed revolutions.

Spending months at a time as a guest of left-wing students in the interior of the country, I lived in villages and urban districts where electric and water services were sporadic if they existed at all, the daily staple was beans and corn, and the people knew the federal police and military to be bandits. In retrospect, I understood very little of the language or culture, but I still remember the poverty.'I was shocked by the economic conditions, not just the beggars that stood on every tourist corner, but also the death that came so young and was so common.

Over the next few years I returned to UW, took some more classes, but had lost interest in academic studies. Instead, my "higher learning" would continue as a gringo gone bad who volunteered to help finance the modest economic development of a few remote Mexican villages. Desperation and youthful idealism is the mother of invention. What was I smoking?

Well, you guessed it. My romantic interest in the plight of the Mexican people introduced me to a strange business, where Yankee green backs flowed 
south and pipe dreams north. In a small way my "work" did contribute to a modest improvement in living conditions for the farmers of a few rural provinces. I have no regrets, certainly not about the friendly people I got to know south of the border, the food and building supplies we trucked to their villages, or the water pipe and electrical service we built. I still remember the smiles on one occasion when we turned on the pumps and the water flowed into the modest homes and the lights went on in the adobe schoolhouse.

Over the next decade I traveled extensively south of the border, returning home to the States, indifferent to the inherent risks, an adventurer playing a dangerous game. I played a role that could only end in disaster. By the end of the 1970s and the beginning of the "drug war" in the early 1980s, many of my friends were dead or in prison. By 1982, I was a bit worn from living on the lunatic fringe, ahead of my time and way outside the law. The years of travel had taken their toll. Still, the work continued, as the Yankee dollars brought hope and relative prosperity to so many people who worked the land in quiet desperation.

Nonetheless, I should not have been so surprised that my own government thought less of my endeavors and decided I was a dangerous criminal. After many years of twilight activities, for which I have few qualms, I was set up by a cowardly pilot in a federal sting operation, and indicted on ten counts of conspiracy to distribute ten tons of imaginary marijuana. In 1984, I started a nine year sentence in the Federal Bureau of Prisons (FBOP).

\section{Penitentiary dReams}

Strange thoughts occupy a person late at night in a penitentiary. As the lights went off in the cellblock, I lay down in my bunk and drifted into sleep. My dream took me back more than ten years. Fifty feet off the deck, with cacti and sage brush below, the twin engines of the Beechcraft roared, the wings fluttering in the dark as we flew beneath the radar, the plane speeding at 200 mph over the Sonora desert. Gritting my teeth, I slammed an eight track into the tape player and turned up the volume. Linda Rondstat belted out "Willing," the music barely heard above the cabin noise.

I woke up in a sweat, confused as to whether my dream was any better than the nightmare of this federal pen. At least I was alive, which is more than I can say for some of my friends who over the years had crashed and burned, or drowned at sea. 
In federal prison I met many men who were drug war refugees. Some were the top echelon that had organized and financed smuggling operations, while others were the hired help, pilots or boat crewmembers. These are the men who smuggled pot from the third world plantations to first world destinations. They came from many countries, many of them ex-military who had fought in real wars, or done time in foreign prisons.

The "ganga soldiers" were my buddies in prison. As a federal prisoner I did time in a number of prisons, including four "mainline" penitentiaries. In every joint I met men serving life sentences for importation or distribution of marijuana. Many of these individuals were non-violent and well-educated victims of their own romantic notions about social change. They pay the price for a social revolution that began in the 1960s, flourished through the 1970s, then got hammered by the Reagan-Bush drug war in the 1980s. Some of them, like myself, live on through new dreams.

\section{THE BOOKS I READ IN PRISON}

I learned in college that the people who run this world read books. From the time I was first jailed in South Carolina, and as I journeyed through nine different prisons in six states, I was preoccupied with reading. I certainly had more "free time" to read in the "joint" than I ever had as an undergraduate or would later have as a graduate student. Locked in a cage, the books kept me alive.

In the penitentiary you do not have access to university or public libraries, so you have to beg friends to mail books in, or work through the shoddy paperback collection of worn out copies found in the library. In letters I requested books, my preference being serious reading, including classical literature, college textbooks, and political theory. In each federal prison I would make frequent visits to the library, scanning the limited collection of books, going from $\mathrm{A}$ to $\mathrm{Z}$, looking for something worth reading. Amid the volumes of trashy fiction, I would find a few gems. In each prison I would get to know a few educated persons who were readers and would lend me their treasures.

I passed the time with Hugo (1987), Cervantes (1981), Dumas (1901), Gramsci (1971), Dostoevsky (1959, 1967), and Solzhenitsyn (1963, 1970, 1973, 1975, 1978) —all celebrated European authors who had served some time in captivity. I read closer contemporaries, also convicts, such as William Reich (1980), George Jackson (1970), Eldridge Cleaver (1967), Malcom X (1969), and Claude Brown (1999). For entertainment, and a respite from convict 
authors, I turned to Kurt Vonnegut (1960, 1966), and Herman Hesse (1982, 1990, 1999).

Planning to return to university upon my eventual release, I brushed up on the physical and social sciences by reading outdated textbooks I managed to find in prison libraries. This allowed me an opportunity to get reacquainted with chemistry, biology, geography, and physics. I read a number of Isaac Asimov's science primers, and his trilogy The Foundation (1982). Carl Sagan's works, especially Cosmos (1980), and other books on astronomy, allowed me to see beyond the narrow confines of my daily existence. Living in prison, locked up at night, with rarely a view of the night sky, I missed the stars.

My political preferences were to catch up on my subversive studies. I read Noam Chomsky and Edward S. Herman (1979), and spent the better part of my final year in the joint with Karl Marx (1973, 1987). The months slipping by, as I completed the three volumes of Capital $(1977,1979,1981)$. Finally, in my last year in prison, as preparation for entering graduate school, I read sociology.

\section{Cllasses In PRISON}

The federal prisons where I was interred had no college classes; the educational program limited to Adult Basic Education ( $\mathrm{ABE}$ eighth grade) and General Equivalency Diploma (GED). Of course, I was forced to participate in the standard "vocational studies," including twelve-hour shifts in the kitchen seven days a week, landscape maintenance, mopping floors, and cleaning bathrooms. No matter the duty, I carried a paperback book in my pants pocket. I was free as long as I could read.

The only institutional program worth remembering was a ten month, eight hour a day, computer repair school, operated on contract by an outside corporation. I enjoyed learning about computer architecture and program languages, but spent most of my time teaching remedial math classes to my fellow convicts. Some of them actually learned enough basic algebra to pass the computer course exams. Unfortunately, this unique prison program was discontinued when the funding expired.

In every prison there was a dedicated group of prisoners, many of them college educated, some of them former teachers, who tutored other men for their $\mathrm{ABE}$ or GED. FBOP policy emphasized the need for prisoners to complete 
these basic requirements. In each prison there was an education office, usually staffed with one hack (officer) and a number of convict clerks. The success of the program depended as much upon the determination of the individual prisoners as upon the skills of the officer. Still, the results were less than impressive, as the atmosphere resembled a penalty study hall in a ghetto high school, with the hack teaching little if at all, and the convict students studying even less. Prisoners who wanted to start or continue their college education were usually given little support or assistance by prison staff. They may have received encouragement from individual officers, but there was little formal institutional support.

Those prisoners that were successful in passing the GED exam were, more than likely, tutored by other convicts one-on-one. They would bring their GED workbooks home to their cells and solicit help. If they were lucky, they found a college-educated prisoner with the patience and good will to help them through the English, math, and science. These teachers enjoyed helping another man learn to read, pass the test, and accomplish something positive.

In every joint there were "classes" organized by the prisoners. Some of these were informal reading circles where a number of men would pass one worn copy of a classic book or political literature, then meet on the yard or work site to discuss what they read. In Terre Haute, a library clerk reintroduced me to the wild works of William Reich. I had already read The Mass Psychology of Fascism (1980) while in college. A group of convicts read Listen, Little Man! (1970) and learned that Reich, a student of Sigmund Freud whose books were outlawed in the US, was imprisoned for his writing and died in federal prison. In Leavenworth, we read Victor Hugo's Les Miserables (1987) and the collected works of Leo Tolstoy, including War and Peace (1982) and The Death of Ivan Ilyich (1991). Hugo's character Jean Valjean is the classic example of a convict struggling for redemption. Tolstoy's short story The Kreutzer Sonata (1987) helped me to better understand the bourgeois concerns of my wife when I received the inevitable divorce papers in Leavenworth.

Semi-formal classes were also organized and improvised by prisoners on a wide range of topics. Many of these were taught by men convicted of whitecollar offenses or tax crimes. I remember entrepreneurial subjects like writing business plans, applying for small business loans, and operating a limousine service. We also had classes in foreign languages, including Spanish taught by Colombians and Mexicans, as well as German and French. The population of 
the FBOP is one-third foreign, with prisoners from all over the world. It was relatively easy to find a tutor. There were also generous instructions by jailhouse lawyers in the art of writing administrative remedies, writs, motions to court, appeals, and post-convict motions. It goes without saying that all of these "classes" were unofficial, with no assistance from prison authorities, as they were free and taught by convict volunteers.

Formal classes, beyond GED, were not available, with rare exception. Occasionally, a local community college might offer one or two introductory level courses, but these were far and few between, depending upon the institution, the whims of the warden, and in any event, only served the few dozen prisoners at a time that could somehow scrounge up the funds to pay the tuition. The community college usually pulled the plug on the program when they discovered the convicts could not afford the courses, losing patience with the Neanderthal bureaucrats that managed the penitentiary. The FBOP, despite their program propaganda, does not support higher education. Most wardens, even those that publicly portray themselves as dedicated to rehabilitation, see outside university instructors as "a threat to the security of the institution."

Prior to 1992, the Federal Pell Grant program, theoretically, was still available for prisoners in both federal and state prisons as a means to pay college tuition for courses taught inside institutions or by correspondence. I know that some prisoners who spent years doing time in one prison were able to access this program, receive funding, and pay for college credits. Unfortunately, this was somewhat more difficult in federal prisons where convicts were transferred frequently. I applied for a number of Pell Grants at different prisons, completed the paper work, and was then shipped out, never receiving the support to pay for college credit.

Later I learned that this was a common experience for many prisoners. Still, it is difficult to know if the midnight transfers were a result of applying for the grant, or resulted from other circumstances; for example, overcrowding, disciplinary infractions, or filing legal motions. Nonetheless, the rumor among federal prisoners was that even though they applied in person for a Pell Grant to pay for their intended college courses, the education office at the prison, and not prisoners, actually received the funds. This money could be spent by the institution on whatever - basketballs, pencils, GED manuals, or even flower gardens for the Warden's house planted by "inmate horticultural students." In any case, I never received a Pell Grant. 


\section{COLLEGE CREDIT BY CORRESPONDENCE}

Most prisons have a small number of prisoners taking college credit by mail. They usually hang out in the prison library or law library where it is quiet and they might have access to typewriters and copy machines. Determined prisoners may complete as many as three to nine course credits in ninety days, depending on their funds to pay for courses and stamps, scholastic ability, the conditions of confinement, and their ability to get along with other prisoners and staff.

I entered prison with 115 college credits towards a Bachelors' Degree in sociology. Still needing fifteen credits to graduate, I went to work in a UNICOR (federal prison industries) cable factory, where we constructed electric cable harnesses under contract for the military. I worked my way up to Grade 1 clerk, and as one of the highest paid prisoners in the facility, made approximately \$200 a month, including overtime. I used my "inmate pay" to pay for college courses by mail. Every month, after making my commissary purchases (food, smokes, stamps, etc.), I would set aside so much to pay for the next course. It took me two years to complete five courses ( 15 credits), and complete the degree requirements for the UW degree. To my knowledge, I was the only prisoner that year in the entire FBOP to complete a college degree.

College credit courses are not for everybody. Prisoners, just like first year students on college campuses, have a high rate of failure. The "good news" is that, ironically, prisons are an ideal place to begin college study. Convicts have lots of time to read, room and board are provided, and for the committed student there may be few distractions. Beginning college in prison on their own initiative, prisoners are planning a new future, reinventing themselves, reaching for freedom. Upon release from prison, the college transcript will help them gain admission to a university to finish the degree.

\section{Comirleting a COLLEGE DEGREE}

Many so-called "traditional" students (aged 18-22), both in prison or the "free world," take years to finish college degrees at large state universities. Very few finish in four years, even those attending classes and living on university campuses. A four-year degree is now really five or six, depending on finances and academic ability. Yes, some students from affluent families graduate in four years, especially those who attend private schools with expensive tuition 
and low academic standards. Still, most working-class students who have to work to pay their own way take five or more years to finish college. "Nontraditional" (older students) now make up a growing population on many college campuses. These are older men and women pursuing higher education later in life, maybe after a career crisis, divorce, military service, or stretch in prison. Many university professors know these students to be above average even gifted individuals who are serious about their studies.

I completed my bachelor's degree in 1986 in prison, so I never attended a ceremony or celebration. Still, I was no less proud of the achievement and looked forward to graduate school.

\section{GraduATE SCHOOL}

In 1987, while on a six-day furlough from Federal Prison Camp (FPC) Oxford, I visited the Department of Sociology at the University of Wisconsin-Milwaukee (UW-Milwaukee) and asked to see the Department Chairperson, Professor Gregory Squires. Upon introducing myself, and informing him I was interested in applying to the Masters Program, I gave him two file folders: one contained my undergraduate university transcripts, the other my prison furlough papers. Squires asked, "Can you teach criminology?" He then called the Dean of Arts and Sciences for permission to admit me to the program with an appointment as a Graduate Teaching Assistant (GTA). His next step was to have his secretary type my application to their graduate program in his office, waive the application fee, and introduce me to some of the faculty. When I returned to FPC Oxford, I used the UW-Milwaukee admission and GTA appointment to secure a sixmonth halfway house.

Released from federal prison in 1987, I entered the Masters Program at UW-Milwaukee. In 1989, upon completing the M.A., I entered the Ph.D. Program in sociology at Iowa State University, graduating in 1992. Today, I am an associate professor of sociology and criminology at Northern Kentucky University.

\section{BeCOMING A UNIVERSISTY PROFESSOR}

It is a long way from Leavenworth to the ivory tower. Earning a Ph.D. was only the first step in becoming a professor. I still needed to overcome the stigma of a criminal record, and learn to manage my identity. If I had chosen 
an academic discipline other than criminology this may have been less of a problem. Nevertheless, the experience I had with the criminal justice system and prisons has provided a real life education in these subjects that goes well beyond the academic training available to most of my colleagues. Unfortunately, some university faculty are threatened by an ex-convict that understands how little they know about the subjects they teach and research.

Many criminology and criminal justice faculty come from sheltered backgrounds. They have little real world knowledge of working class lives, let alone the perils of poverty, or the struggles of convicts. Yes, they have Ph.D.s, and through many years of studying their discipline they do acquire considerable insight into why people do crime. Still, they never really get it. Which is no surprise, considering they never bothered to talk with convicts. Many academics who claim to be prison scholars, and write books on the subject, have spent precious little time inside of prisons, and even then only on escorted tours.

No wonder most prison literature reads like fairy tales (this journal being one exception). Textbooks talk about constitutional amendments, the Bill of Rights, prisoner's rights, prison programs, and rehabilitation. Ideally prisoners should have these protections and services. Unfortunately, most textbooks paint a false picture of reality, and as such do a disservice to students.

I have learned that becoming a professor means I do not have to suffer fools or foolish books. I have no patience for social scientists who study their subject from a safe distance. Fortunately, we have a growing group of "convict criminologists" that have the courage to do the science and "tell it like it is."

\section{Convict Criminologists}

Today, even while working to fit in and play the professor role, I enjoy my excon status. As one of the leaders of the Convict Criminologists, a growing group of ex-convict criminology faculty, I prefer the company of my "felonious friends" who, although they have fancy college degrees, have not forgotten from where they came.

Since 1997, the Convict Criminologists has grown in numbers and strength. The group includes faculty and graduate students, both ex-cons and "noncons." The core of the group is the ex-cons. Still, the group has been successful because of the many contributions of talented non-con critical criminologists. It is the need to do science the truth that holds us together and drives our efforts to research and publish. 
We do conference sessions, including the American Society of Criminology, Academy of Criminal Justice Sciences, even the American Correctional Association (ACA). Many of these presentations have drawn large audiences. Ironically, our 2001 plenary session at the ACA conference in Philadelphia drew the largest and most enthusiastic crowd yet. In retrospect, I think the correctional administrators and "line staff" were proud of their "bad boys" that had made good.

As a group we have formed our own cyberspace "convict department". We use e-mail to communicate, coordinate research and publication, and mentor graduate students. The ex-con professor writing tradition began with John Irwin $(1970,1980,1985)$. The list of significant publication has grown as new colleagues are added. ${ }^{1}$ Convict Criminology (Ross and Richards, 2003) includes chapters by eight ex-convict academics. Our non-con critical criminology friends write some of the best chapters in this new volume.

\section{CONCLUSION: BOOKS WILL TAKE YOU ANYWHERE YOU WANT TO GO}

I have shared my own story to demonstrate that even while in prison men and women can begin new dreams through higher education. University study has been demonstrated by research to be the single best means to post-prison success. A prison record and a GED provide men and women released from prison with few prospects other than minimum wage jobs and a limited future. Prisoners who complete university credit courses while incarcerated may continue on and finish college degrees at universities upon release from prison.

After getting out of prison, one possible path is to go to college. Former prisoners make good university students, as they are already institutionalized, familiar with dormitory living, cafeteria food, and bureaucratic rules. Considering they will have a difficult time finding a decent job, have no income, and have not paid taxes in years, they will qualify for generous student loans and possible grants. Besides, universities are dream machines, the places where people go to learn and grow and remake their lives.

Newbold, 1982/1985, 1989, 1991, 2000; Jones and Schmid, 1989, 1993, 2000; Richards and Jones, 1997; Terry, 1997, 2003; Mobley and Geis, 2000; Austin et al., 2001; Austin and Irwin, 2001; Richards and Ross, 2001; Richards et al., 2002; and Ross and Richards $2002,2003$. 
In my experience as both a convict and professor, I know ex-convicts to make good students. I have had many ex-convict students in my classes that study hard, get good grades, and graduate with honors. Like many nontraditional students, they are serious learners and masters at overcoming adversity. Taxpayers need to figure out that it costs much less to send individuals to college than keep them locked up in prison. Then again, maybe I am still dreaming. In any case, remember, books will take you anywhere you want to go.

\section{REFERENCES}

Asimov, I. (1982). The Foundation Trilogy: Three Classics of Science. Garden City: Doubleday.

Austin, J., et al. (2001). "The Use of Incarceration in the United States." American Society of Criminology National Policy Committee. Critical Criminology: An International Journal, 10:1, 17-41.

Austin, J. and Irwin, J. (2001). It's About Time. Belmont, CA: Wadsworth.

Brown, C. (1999). Manchild in the Promised Land. New York: Simon \& Schuster.

Cervantes, M. (1981). Don Quixote. New York: Norton.

Chomsky, N. and Herman, E.S. (1979). The Washington Connection and Third World Fascism. Boston: South End Press.

Cleaver, E. (1967). Soul on Ice. New York: McGraw-Hill.

Debray, R. (1980). The Revolution in the Revolution. New York: Greenwood Press.

Dostoevsky, F. (1959). Crime and Punishment (Trans. by Princess Alexandra Kropotkin). Garden City: Literary Guild. (1967). The Idiot (Trans. by E.M. Martin). London: Dutton.

Dumas, A. (1901). The Count of Monte-Cristo. New York: T.Y. Crowell.

Fanon, F. (1976a). The Wretched of the Earth. New York: Grove/Atlantic. . (1976b). Black Skin, White Masks. New York: Grove/Atlantic

Gramsci, A. (1971). Selections from the Prison Notebooks. New York: International Publishers. Hesse, H. (1982). Siddhartha. New York: Bantam. . (1990). The Glass Bead Game. New York: Henry Holt. . (1999). Demian. New York: HarperCollins.

Hugo, V. (1987). Les Miserables. New York: Signet.

Irwin, J. (1970). The Felon. Englewood Cliffs: Prentice-Hall. . (1980). Prisons in Turmoil. Boston: Little, Brown. . (1985). The Jail. Berkeley: University of California Press.

Jackson, G. (1970). Soledad Brother: The Prison Letters of George Jackson. New York: Putnam.

Jones, R.S. and Schmid, T. (1989). "Inmates' Conception of Prison Sexual Assault.” The Prison Journal, 69: 53-61. . (1993). "Ambivalent Actions: Prison Adaptation Strategies of First-Time, ShortTerm Inmates.” Journal of Contemporary Ethnography, 21:4, 439-463. 
(2000). Doing Time: Prison Experience and Identity among First Time Inmates.

Stamford, CT: JAI Press.

Malcolm X. (1969). The Autobiography of Malcolm X. New York: Random House.

Marx, K. (1973). Grundrisse. New York: Harmondsworth. (1977). Capital, Volume 1. New York: Vintage Books. (1979). Capital, Volume 2. New York: Vintage Books. (1981). Capital, Volume 3. New York: Vintage Books.

(1987). The Eighteenth Brumaire of Louis Bonaparte. New York: International.

Mobley, A. and Geis, G. (2000). "The Corrections Corporation of America AKA the Prison Realty Trust." In M. Gilbert and D. Shichor (Eds.), Privatization in Criminal Justice: Past, Present and Future. Cincinnati: Anderson.

Newbold, G. (1982/1985). The Big Huey. Auckland, NZ: Collins. (1989). Punishment and Politics: The Maximum Security Prison in New Zealand. Auckland, NZ: Oxford University Press. (1991). "What Works in Prison Management: Effects of Administrative Change in New Zealand." Federal Probation, 56:4, 53-57. (2000). Crime in New Zealand. Palmerston North, NZ: Dunmore.

Reich, W. (1970). Listen, Little Man! New York: Farrar Straus \& Giroux. (1980). The Mass Psychology of Fascism. New York: Farrar Straus \& Giroux.

Richards, S.C. and Jones, R.S. (1997). "Perpetual Incarceration Machine: Structural Impediments to Postprison Success." Journal of Contemporary Criminal Justice, 13:1, 4-22.

Richards, S.C. and Ross, J.I. (2001). "The New School of Convict Criminology.” Social Justice, 28:1, 177-190.

Richards, S.C., Terry, C.M., and Murphy, D.S. (2002). "Lady Hacks and Gentlemen Convicts.” In L.F. Alarid and P. Cromwell (Eds.), Contemporary Correctional Perspectives: Academic, Practitioner, and Prisoner. Los Angeles: Roxbury.

Ross, J.I. and Richards, S.C. (2002). Behind Bars: Surviving Prison. Indianapolis: Alpha Books.

(2003). Convict Criminology. Belmont, CA: Wadsworth.

Sagan, C. (1980). Cosmos. New York: Random House.

Solzhenitsyn, A. (1963). One Day in the Life of Ivan Denisovich. New York: Signet Books. . (1970). First Circle. New York: Bantam Books. . (1973). The Gulag Archipelago: Book I-II. New York: Harper \& Row. . (1975). The Gulag Archipelago: Book III-IV. New York: Harper \& Row. . (1978). The Gulag Archipelago: Book V-VII. New York: Harper \& Row.

Terry, C.M. (1997). “The Function of Humor for Prison Inmates.” Journal of Contemporary Criminal Justice, 13:1, 23-40.

Tolstoy, L. (1967). “The Kreutzer Sonata.” In L. Tolstoy, Great Short Works of Leo Tolstoy (Trans. by L. Maude and A. Maude). New York: Harper \& Row, pp. 353-450. . (1982). War and Peace. London: Viking Penguin. (1991). Death of Ivan Ilych. London: Penguin

Traven, B. (1970). The Carreta. New York: Hill \& Wang. . (1972). General from the Jungle. New York: Hill \& Wang.

. (1991). The Death Ship: The Story of an American Sailor. Chicago: Chicago Review Press. 
Vonnegut, K., Jr. (1960). Cat's Cradle. New York: International Thomson Publishing. . (1966). Mother Night. New York: HarperCollins.

Stephen C. Richards, a former federal prisoner, is Associate Professor of Sociology and Criminology at Northern Kentucky University. He is a Soros Senior Justice Fellow. Some of his recent work includes Behind Bars: Surviving Prison (Alpha) and Convict Criminology (Wadsworth) with Jeffrey Ian Ross. He can be contacted at richards@nku.edu. 